\title{
An Empirical Study on Perception of Corporate Professionals towards Individual Work Vs Group Work
}

\author{
Varalakshmi .T \\ Lecturer, MBA Department, DonBosco Institute of Biosciences \& Management Studies, Bangalore, India
}

\begin{abstract}
In a wide variety of organizational settings, Organizations generate a number of possible solutions to a problem; Here we examine the effectiveness of two creative problem solving processes for such tasks - one, where the group works together as a team (the team process), and the other where individuals work alone. The concepts of teamwork have penetrated nearly every segment of the business world in recent decades as a sign of efficiency but most of the times teams doesn't produce the required results as the group members remain focused on their individual needs and give rise to group conflicts. This is why the reasons many corporate professionals like to work alone which makes them more authenticate, elated and give recognition to their individual efforts. What therefore seems relevant by the study is - "How the corporate professionals perceive themselves being a team member or an individual performer?" - "Which are better at performing tasks? - groups or individuals"
\end{abstract}

Keywords: Creativity, Brainstorming, Innovation, Team, Group, Team process, Individuals, Efficiency.

\section{Introduction}

The value of the collaborative effort (teamwork) in business has gained significant popularity in the recent past. More and more businesses are introducing teamwork as a sign of efficiency in their production processes for improved quality. An obvious advantage of team work is the higher resources of a team as compared to the individual.

"A collection of individuals who have regular contact and frequent interaction, mutual influence, common feeling of camaraderie, and who work together to achieve a common set of goals."

Success depends on group work' - we can't reach this conclusion too hastily, Teams are not appropriate for all organizations or in all types of businesses. In reality, the teamwork approach does not always work well. Apollo Syndrome is a good example of this - where a team composed of highly intelligent people often performs worse than teams made of up of less capable members.

There are some corporate professionals who would like to work alone, especially (i) when group members are not cooperative, (ii) when task demands high degree of concentration, (iii) when individual performance has to be recognized, (iv)when an individual has to work at their own pace \& (v) when the group members tend to escape from their work.

\subsection{Individual Work Vs Group Work}

Registering a dramatic change, from the more overtly authoritarian structure of traditional firms to democratic style, companies have focused on group work for the following reasons.

"In order to be open to creativity, one must have the capacity for constructive use of solitude. One must overcome the fear of being alone." $\sim$ Rollo May

\subsubsection{Advantages of Being A Team Member -}

1. Varied cultures, age groups, gender, etc all add to the diversity of group which gives us varied perspectives and enhances the ideologies.

2. An individual may forget a particular piece of information, but as there are a number of people involved here, there is the combined memory of all members to recollect data.

3. As everyone has made some contribution to the decision, people tend to accept the collective decisions.

4. The members together come to a decision after much deliberation and discussions and so everyone has a better understanding of the course of action to be followed.

5. With so many people involved, more creative and innovative solutions to problems may emerge than an individual may have been able to develop.

6. There are a number of people involved, so no one person has to shoulder the burden of work or of single handedly making a decision.

\subsubsection{Advantages of Being An Individual Performer -}

But working in groups is not always a pleasant job. Anyone who ever had to coordinate activities and come to decisions in conjunction with other people always like to work as an individual for the following 
reasons.

1. Working alone gives more autonomy and power to decide. it enables acting according to one's judgment without facing criticism.

2. Entire responsibility lies in one hand, Hence an individual can set his own standards.

3. Results in self satisfaction and recognition of individual performance.

4. It helps an individual to connect with himself and assemble thoughts and ideas in a way that's unique to him.

\section{Objectives Of The Study}

With the backdrop, the present study mainly focuses on achieving the following specific objectives:

1. To know how the corporate professionals perceive working in groups.

2. To study which is more productive - being an individual performer or a team member.

3. To identify the factors that determines the employee's perception to work alone.

\section{RESEARCH GAP}

The above research study spotlights the two different but related areas (i) performing individually \& (ii) performing as a team member. Furthermore, study was undertaken to investigate the area having high perceived value according to corporate professionals i.e., whether they prefer to work individually or as a team member.

\section{LITERATURE REVIEW}

A Arthur Friedrich (2011) The value of a contributor decreases disproportionately with each additional person contributing to a single project, idea, or innovation.

A Cannon-Bowers, Tannenbaum, Salas, and Volpe, (1995) Individual competencies are those requirements that are needed for effective individual performance.

A Huey and Wickens (1985) The decomposition of teamwork competencies like, knowledge, skills, and attitudes, begins to open the door for understanding the relationship between human performance at different levels.

A Jeffrey Stibel (2011) Great individuals are not only more valuable than legions of mediocrity, they are often more valuable than groups that include great individuals.

A Katzenbach (1998) Individuals are more authenticate when they work alone as they have complete autonomy in determining how a task should be done.

A Livingstone and Lynch (2000) The composition of the group is a key consideration when choosing group work.

A Napier \& Gershenfeld, (1999) Group members remain focused on their individual needs and conflict in the group increases, and the group members blame others for failures.

A Robbins and Finley, (2000) Group work is used for many reasons: to manage a large cohort; to develop appropriate skills in collaboration; to simulate a real work environment; etc, and is considered by some to "lead to greater efficiency and effectiveness" whilst others believe that "teams are inherently inferior to individuals, in terms of efficiency"

\section{RESEARCH METHODOLOGY}

This present research study was done using primary data. The instrument used to collect the data was online survey with a Structured Questionnaire. The data was collected from 3 different companies' ${ }^{1}$ and hence finally 106 employees were chosen as respondents through Convenient Sampling Method.
The required
by divided it into

three different parts -

Part - A - Chi square test to find out the relationship between the underlying dimensions \& the preference of the respondents.

Part - B - Weighted Average Method \& Ranking Method to know the factor which motivates the respondents to the highest resulting in their positive preference towards group work.

Part - C - Simple Average Method to know which is more advantageous \& effective whether it is being a team member or an individual performer.

\footnotetext{
${ }^{1}$ The data required for the analysis was collected from 3 different companies like, Accenture, Infosys \& J.P. Morgan employees.
} 
VI. ANALYSIS AND INTERPRETATION

Table-1

Demographic profile of the Respondents

\begin{tabular}{|c|c|c|c|}
\hline Demographic factors & Category & $\begin{array}{l}\text { No. } \\
\text { Respondents }\end{array}$ & $\begin{array}{l}\text { Percentage } \\
(\%)\end{array}$ \\
\hline \multirow{3}{*}{ Gender } & Male & 68 & 64.15 \\
\hline & Female & 38 & 35.85 \\
\hline & Total & 106 & 100 \\
\hline \multirow{6}{*}{ Age } & Below 25 yrs & 60 & 56.60 \\
\hline & $25-35$ yrs & 38 & 35.85 \\
\hline & $35-45 \mathrm{yrs}$ & 02 & 1.89 \\
\hline & $45-55 \mathrm{yrs}$ & 02 & 1.89 \\
\hline & Above 55 yrs & 04 & 3.77 \\
\hline & Total & 106 & 100 \\
\hline \multirow{3}{*}{ Marital Status } & Married & 36 & 33.96 \\
\hline & Unmarried & 70 & 66.04 \\
\hline & Total & 106 & 100 \\
\hline \multirow{3}{*}{ Educational Qualification } & Graduation & 50 & 47.17 \\
\hline & Post Graduation & 56 & 52.83 \\
\hline & Total & 106 & 100 \\
\hline \multirow{3}{*}{ Industry } & Service / IT Sector & 92 & 86.79 \\
\hline & Manufacturing Sector & 14 & 13.21 \\
\hline & Total & 106 & 100 \\
\hline \multirow{4}{*}{ Income (p.a) } & Below 2.5 Lakhs & 54 & 50.94 \\
\hline & $2.5-3.5$ Lakhs & 20 & 18.87 \\
\hline & Above 3.5 Lakhs & 32 & 30.19 \\
\hline & Total & 106 & 100 \\
\hline
\end{tabular}

Table 1 indicates that -

(i) $64.15 \%$ of the respondents are male and the rest are female.

(ii) Majority of the respondents i.e., 56.60 are below the age group of 25 yrs, where as $35.85 \%$ fall into the category of $25-35$ yrs rest are the respondents who are above the age group of $35 \mathrm{yrs}$.

(iii) Nearly $66.04 \%$ of the respondents are unmarried and the rest are married.

(iv) $52.83 \%$ of respondents are qualified with Masters Degree where as remaining $47.17 \%$ are only Under Graduates.

(v) Among the respondents $86.79 \%$ are the employees in service / IT sector, remaining 13.21 are engaged in manufacturing sector.

(vi) Majority of respondents fall into the income bracket of below 2.5 Lakhs p.a, 18.87\% between $2.5-3.5$ Lakhs remaining earn above 3.5 Lakhs p.a.

PART - A

Table-2

Reasons as to why the respondents prefer individual work rather than group work

$\mathbf{H}_{\mathbf{0}}=$ There is no significant difference between the respondents preference towards Group work that it is impacted by the factors like task definition, confusion, less co-ordination.

$\mathbf{H}_{1}=$ There is significant difference between the respondents preference towards Group work that it is impacted by the factors like task definition, confusion, less co-ordination.

\begin{tabular}{|l|l|l|l|l|l|}
\hline Parameters & $\mathbf{O}$ & $\mathbf{E}$ & $(\mathbf{O}-\mathbf{E})$ & $(\mathbf{O}-\mathbf{E}) \mathbf{2}$ & $(\mathbf{O}-\mathbf{E}) \mathbf{2} / \mathbf{E}$ \\
\hline $\begin{array}{l}\text { Task not clearly } \\
\text { defined }\end{array}$ & 06 & 21.2 & 15.2 & 231.04 & 10.89 \\
\hline $\begin{array}{l}\text { Time } \\
\text { Consuming }\end{array}$ & 20 & 21.2 & -1.2 & 1.44 & 0.07 \\
\hline
\end{tabular}


An Empirical Study on Perception of Corporate Professionals towards Individual Work

\begin{tabular}{|l|l|l|l|l|l|}
\hline $\begin{array}{l}\text { Confusion in } \\
\text { assigning the } \\
\text { work }\end{array}$ & 14 & 21.2 & -7.2 & 51.84 & 2.45 \\
\hline $\begin{array}{l}\text { Less Co - } \\
\text { ordination b/w } \\
\text { team members }\end{array}$ & 32 & 21.2 & 10.8 & 116.64 & 5.50 \\
\hline $\begin{array}{l}\text { Non recognition } \\
\text { of individual } \\
\text { performance }\end{array}$ & 34 & 21.2 & 12.8 & 163.84 & 7.73 \\
\hline Total & $\begin{array}{l}\square \mathbf{O} \\
106\end{array}$ & $\square \mathbf{E}=106$ & & & $\begin{array}{l}\chi_{\text {cal }}^{2} \\
26.64\end{array}$ \\
\hline
\end{tabular}

The above table shows that, there is a significant level of inclination of the respondents towards group work, as

$$
\left(\mathrm{i}, \chi_{\text {cal }}^{2} 26.64 \chi_{\text {tab }}^{2.488)}\right.
$$

Hence, $\mathbf{H}_{\mathbf{0}}$ is rejected at 4 degree of freedom $\& 0.05$ of level of significance.

Table-3

Level of relationship between level of Creativity and Innovation fostered due to Individual work.

$\mathbf{H}_{\mathbf{0}}=$ There is no significant level of relationship between level of Creativity and Innovation fostered due to individual work.

$\mathbf{H}_{\mathbf{1}}=$ There is significant level of relationship between level of Creativity and Innovation fostered due to individual work.

\begin{tabular}{|l|l|l|l|l|l|}
\hline Parameters & $\mathbf{O}$ & $\mathbf{E}$ & $(\mathbf{O}-\mathbf{E})$ & $(\mathbf{O}-\mathbf{E}) \mathbf{2}$ & $(\mathbf{O}-\mathbf{E}) \mathbf{2} / \mathbf{E}$ \\
\hline $\begin{array}{l}\text { Strongly } \\
\text { Agree }\end{array}$ & 10 & 21.2 & -11.2 & 125.44 & 5.91 \\
\hline Agree & 40 & 21.2 & 18.8 & 353.44 & 16.67 \\
\hline $\begin{array}{l}\text { Neither } \\
\text { Agree nor } \\
\text { Disagree }\end{array}$ & 38 & 21.2 & 16.8 & 282.24 & 13.31 \\
\hline Disagree & 18 & 21.2 & -3.2 & 10.24 & 0.48 \\
\hline $\begin{array}{l}\text { Strongly } \\
\text { Disagree }\end{array}$ & 0 & 21.2 & -21.2 & 449.44 & 21.2 \\
\hline Total & $\square \mathbf{O}=106$ & $\square \mathbf{E}=106$ & & & $\begin{array}{l}\chi^{2} \text { cal } \\
57.57\end{array}$ \\
\hline
\end{tabular}

The above table shows that, there is a significant level of inclination of the respondents towards group work, as (i.e., 57.57 > 9.488) $\chi_{\text {cal }}^{2}>\chi_{\text {tab }}^{2}$

Hence, $\mathbf{H}_{\mathbf{1}}$ is accepted at 4 degree of freedom \& 0.05 of level of significance.

Table-4

Preference of Corporate professionals towards Group work

$\mathbf{H}_{\mathbf{0}}=$ There is no significant level of inclination towards group work.

$\mathbf{H}_{\mathbf{1}}=$ There is significant level of inclination towards group work.

\begin{tabular}{|c|c|c|c|c|c|}
\hline Parameters & O & $\mathbf{E}$ & $(\mathbf{O}-\mathbf{E})$ & $(\mathbf{O}-\mathbf{E}) 2$ & $\begin{array}{l}(\mathbf{O}-\mathbf{E}) 2 / \\
\mathbf{E}\end{array}$ \\
\hline $\begin{array}{l}\text { Group } \\
\text { Conflict }\end{array}$ & 06 & 17.7 & -11.7 & 136.89 & 7.733 \\
\hline $\begin{array}{l}\text { Social } \\
\text { Loafing }\end{array}$ & 18 & 17.7 & 0.3 & 0.09 & 0.005 \\
\hline $\begin{array}{l}\text { Shared } \\
\text { Responsibility }\end{array}$ & 62 & 17.7 & 44.3 & 1962.49 & 110.88 \\
\hline $\begin{array}{l}\text { Role } \\
\text { Ambiguity }\end{array}$ & 08 & 17.7 & -9.7 & 94.09 & 5.34 \\
\hline Feel Secured & 06 & & & & \\
\hline $\begin{array}{l}\text { Base for } \\
\text { Social contact }\end{array}$ & $\begin{array}{l}12 \\
06\end{array}$ & 17.7 & -5.7 & 32.49 & 1.84 \\
\hline
\end{tabular}


An Empirical Study on Perception of Corporate Professionals towards Individual Work

\begin{tabular}{|l|l|l|l|l|l|}
\hline Total & $\square \mathbf{O}=106$ & $\square \mathbf{E}=106$ & & & $\chi_{\text {cal }}^{2}=$ \\
\hline
\end{tabular}

Here as the cell frequencies are less than 5, Pooling Method of Chi square distribution is used. The above table shor ${ }^{2}>\chi^{2}$ significant level of inclination of the respondents towards group work, as (i.e., $125.80>11.07\left(\chi_{\text {cal }}^{2}>\chi_{\text {tab }}^{2}\right.$

Hence, $\mathbf{H}_{\mathbf{0}}$ is rejected at 5 degree of freedom \& 0.05 of level of significance.

PART - B

Table - 5

Motivating factors for Corporate Professionals to prefer Group work

\begin{tabular}{|l|l|l|l|l|l|l|l|}
\hline Parameters & $\begin{array}{l}\text { Strongl } \\
\text { y Agree }\end{array}$ & Agree & $\begin{array}{l}\text { Neither } \\
\text { Agree nor } \\
\text { Disagree }\end{array}$ & Disagree & $\begin{array}{l}\text { Strongly } \\
\text { Disagree }\end{array}$ & Total Score & $\begin{array}{l}\mathbf{R} \\
\mathbf{a} \\
\mathbf{n} \\
\mathbf{k}\end{array}$ \\
\hline $\begin{array}{l}\text { Working in a } \\
\text { team boosts } \\
\text { self confidence } \\
\& \text { self esteem }\end{array}$ & 46 & 44 & 06 & 08 & 02 & $442(25.67)$ & II \\
\hline $\begin{array}{l}\text { Best way to } \\
\text { reach their } \\
\text { goals is thr } \\
\text { team work }\end{array}$ & 26 & 48 & 22 & 04 & 06 & $402(23.34)$ & I \\
\hline $\begin{array}{l}\text { Working in a } \\
\text { team makes } \\
\text { employees fell } \\
\text { more authentic }\end{array}$ & 34 & 48 & 18 & 04 & 02 & $426(24.74)$ & II \\
\hline $\begin{array}{l}\text { Brain storming } \\
\text { in a group is } \\
\text { more effective } \\
\text { than Brain } \\
\text { storming alone. }\end{array}$ & 54 & 36 & 08 & 06 & 02 & $452(26.24)$ & I \\
\hline
\end{tabular}

In the above table, different motivating factors favoring group work were given a weighted average. Starting from Strongly Agree to Strongly Disagree following the weights $5-1$ respectively.

The overall view of the above table indicates that, Brain storming is one of the very important factor which motivates the respondents to prefer group work as it has highest ranking with $26.24 \%$ followed by self confidence \& self esteem with $25.67 \%$. Authenticity stands in the third position with $24.74 \%$. Finally group work as the better way to reach individual goals with $23.34 \%$.

PART - C

Table - 6

Comparative Analysis between Individual work \& Group work

\begin{tabular}{|l|l|l|}
\hline Parameters & Individual work & Group work \\
\hline $\begin{array}{l}\text { Supports } \\
\text { productivity \& Quality } \\
\text { assurance }\end{array}$ & 24 & 82 \\
\hline $\begin{array}{l}\text { Decision is most effective \& } \\
\text { efficient }\end{array}$ & 26 & 80 \\
\hline More Advantageous & 24 & 82 \\
\hline Total & 74 & 244 \\
\hline
\end{tabular}

Calculation of Average no. of respondents favoring individual work vs. group work -

(i) Individual work $=74 / 3=\mathbf{2 4 . 6}$

\footnotetext{
${ }^{2}$ Comparative Analysis was undertaken to know the factor having high perceived value, whether it is working alone or as a team member.
} 
(ii) Group work $=244 / 3=\mathbf{8 1 . 3}$

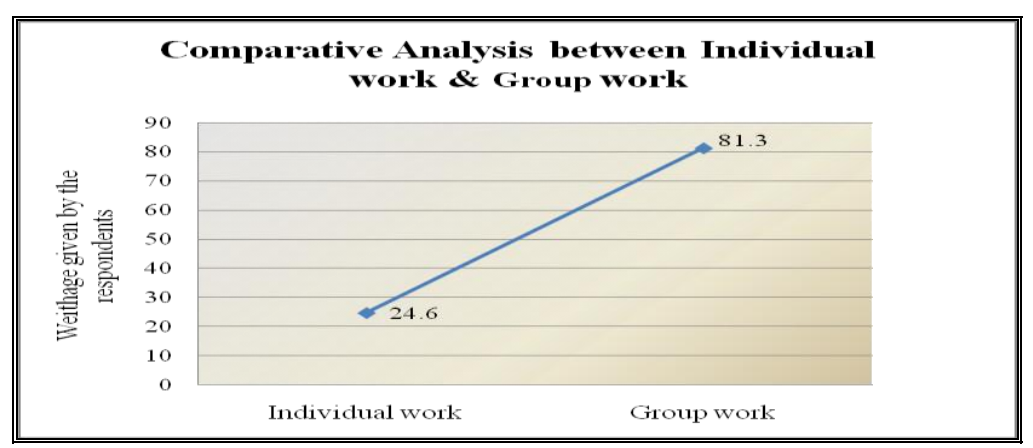

The above table of comparative analysis indicates, that Group work is more advantageous \& effective in terms of Decision making, Higher productivity \& Improved Quality than Individual work as more no. of respondents (i.e., 81.3) prefer Group work as a best way to reach individual goals and finally succeed in their professional life.

\section{Findings}

Based on the summary of the analysis \& interpretation of the above data, the following findings are compiled:

1. Majority of the respondents are Male \& fall into the category of below 25 yrs.

2. Most of them are post graduates employed in service / IT sector thereby earning below 2.5 Lakhs p.a

3. Reasons as to why the respondents prefer to be an individual performer is -

a.Confusion in the work assigned

b.less coordination between team members

c. Non recognition of individual performance.

4. Respondents who agree as well as disagree in their opinion that the level of relationship between level of Creativity and Innovation fostered due to individual work are in equal no.

5. Majority of the respondents have positive preference towards being a team member as it results in shared responsibility.

6. It is the Brainstorming session followed by self confidence \& self esteem that will be boosted up in group work which motivates the employees to the higher extent to prefer group work.

7. Its nearly $81.3 \%$ of respondents out of 106 who prefer group work \& only minimal no. (i.e., 24.6\%) who prefer to be an individual performer.

8. Both the individual work as well as group work both has its own pros \& cons.

\section{Suggestions}

Success behind these concepts of individual work or group work entirely depends upon the employees, as to how they would behave when they are a team member or an individual performer \& what kind of attitude they hold towards these concepts.

In light of this fact I would recommend the following suggestions to the corporate professionals:

1. Colleagues at their work centre should be well behaved, civilised \& possess a character of good conduct with respect to the initial step of Gel - up with the other employees, working together towards the progression \& contributing for the welfare of the company - if the team work has to succeed.

2. In a Team work, there are few essential points to be kept in mind.

a) Difference of opinion may arise amongst employees in terms of ideas, innovation, discovery \& as on. Each one should be given a chance to exhibit their talent, capabilities which are beneficial to the organisation.All should adhere to their consent after a discussion amongst them based on judgement. (Right or wrong)

b) Under estimating, rejecting or refusing will lead to conflicts \& create an unhealthy environment. Hence the Team Lead (TL) should be very cautious about these things.

c) All should be treated uniformly by avoiding the feeling of inferior or superior complexities which may arouse amongst working in a cluster of employees.

3. Finally, "Unity is strength" - holds good, only when all the team mates give up their ego, arrogance, being adamant, unfaithful to each other, concealing the facts that needs to be shared, grudge, envious \& so on which can never form a healthy, inspiring, well-built, \& a friendly team.

Infact, each \& every employee should show \& take their personal interest, dedication, determination towards their work assigned to them. Employee-Employer relationship should also be in good terms. 


\section{Conclusion}

Differing personalities, tension for resources, conflict are all part and parcel of organizational life. If you want a high performance team it is imperative that you provide each and every person in the team with the skills to hold challenging and difficult conversations, to negotiate differences, to provide performance improvement feedback. In case if you expect to be an individual performer see to that you handle all the responsibilities well, without giving any chance for others to win over you or else blame you. Because -

\section{"Coming together is a beginning. Keeping together is progress. Working together is success"}

\section{$\sim \underline{\text { Henry Ford }}$}

\section{Aknowledgement}

I am Varalakshmi .T, Lecturer in DonBosco Institute of Biosciences \& Management Studies, Bangalore, India. I assure that this is my original Study and the findings and suggestions of the above article are genuine.

\section{References}

[1] Cannon-Bowers, J.A., Tannenbaum, S.I., Salas, E., and Volpe, C.E. (1995) Defining Competencies and Establishing Team Training Requirements in Team Effectiveness and Decision Making in Organization.

[2] Huey, B.M. and Wickens, C.D. (1995) Workload Transition: Implications for Individual and Team Performance. National Academy Press: Washington, DC.

[3] Katzenbach, Jon R., ed. The Work of Teams. Cambridge, MA: Harvard Business School Press, 1998.

[4] Livingstone, D. \& Lynch, K. (2000), "Group Project Work and Student-centred Active Learning: two different experiences" in Studies in Higher Education, V25, No 3, October 2000, pp. 325-345.

[5] Napier, W.N. \& Gershenfeld, M.K (1999), Groups: Theory and Experience. Sixth Edition. Boston: Houghton Mifflin.

[6] Robbins .H \& Finley .M (2000), Why Teams Don't Work: What went wrong and how to make it right.

[7] West, Michael A. (1994), Effective Teamwork. The British Psychological Society.

[8] Websites-http://blogs.hbr.org/cs/2011/06/why_a_great_individual_is_bett.html 